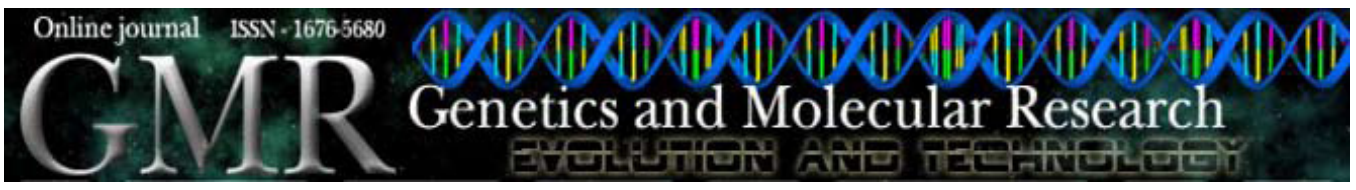

\title{
Diallel analysis of leaf disease resistance in inbred Brazilian popcorn cultivars
}

\author{
R.A. Vieira ${ }^{1}$, C.A. Scapim ${ }^{1}$, L.M. Moterle ${ }^{1}$, D.J. Tessmann ${ }^{1}$, T.V. Conrado ${ }^{1}$ \\ and A.T. Amaral Júnior ${ }^{2}$ \\ ${ }^{1}$ Departamento de Agronomia, \\ Universidade Estadual de Maringá, Maringá, PR, Brasil \\ ${ }^{2}$ Universidade Estadual do Norte Fluminense Darcy Ribeiro, \\ Laboratório de Melhoramento Genético Vegetal, Campos dos Goytacazes, RJ, Brasil \\ Corresponding author: C.A. Scapim \\ E-mail: cascapim@uem.br
}

Genet. Mol. Res. 8 (4): 1427-1436 (2009)

Received July 14, 2009

Accepted September 29, 2009

Published December 1, 2009

ABSTRACT. We estimated general and specific combining abilities and examined resistance to northern leaf blight (Exserohilum turcicum) and to gray leaf spot (Cercospora zeae-maydis) in a set of nine inbred popcorn lines. These inbreds were crossed in a complete diallel scheme without reciprocals, which produced $36 \mathrm{~F}_{1}$ hybrids. Two experiments with a square lattice design and three replications were conducted during the 2008/2009 crop season, in Maringá, PR, Brazil. The severity of northern leaf blight and gray leaf spot was assessed under natural infestation conditions. Data were examined by individual and joint analysis of variance. Individual and joint Griffing's diallel analyses were carried out for adjusted means. General combining ability and specific combining ability were significant $(\mathrm{P}<0.10)$ by the F-test for northern leaf blight and gray leaf spot infestation levels. This denotes that additive and non-additive gene effects both contributed to resistance to these diseases, but that the additive gene effects were more important. Among the inbred lines, $\mathrm{P}_{8}$ and $\mathrm{P}_{9}$ gave the highest resistance to northern leaf blight, and $\mathrm{P}_{3}$ and $\mathrm{P}_{4.3}$ gave the highest resistance to gray leaf spot. The hybrids $\mathrm{P}_{7.4} \times \mathrm{P}_{8}$ and $\mathrm{P}_{4.3} \times \mathrm{P}_{9}$ could be exploited by reciprocal recurrent selection to provide genotypes with both northern leaf blight and gray leaf spot resistance. Significant interaction between general combining 
ability and crop season $(\mathrm{P}<0.10)$ denotes the importance of environment, even though the disease levels in the hybrids were quite consistent.

Key words: Zea mays L.; Combining ability; Northern leaf blight; Exserohilum turcicum; Gray leaf spot; Cercospora zeae-maydis

\section{INTRODUCTION}

Since the advent of reduced tillage production systems and the continuous sowing of the same crop year round, in two agricultural seasons, leaf diseases of corn have greatly increased in their importance in Brazil. Furthermore, many commercial genotypes are susceptible to leaf diseases, and the cropping season is coincident with the rainy season. In this respect, northern leaf blight (NLB), caused by Exserohilum turcicum (Pass.) Leonard \& Suggs, teleomorph Setosphaeria turcica (Luttrell) Leonard \& Suggs and gray leaf spot (GLS), caused by Cercospora zeae-maydis Tehon \& Daniels, have been among the most prevalent diseases.

The development of disease-resistant genotypes is one of the main objectives of corn breeding programs. Studies of combining ability and gene effects on leaf disease resistance have been extensively carried out in sets of common corn genotypes aiming to determine the most appropriate breeding methods. In general, additive genes have greater importance than nonadditive genes for controlling both NLB and GLS (Thompson et al., 1987; Huff et al., 1988; Sigulas et al., 1988; Elwinger et al., 1990; Ulrich et al., 1990; Donahue et al., 1991; Gevers et al., 1994; Carson, 1995; Menkir and Ayodele, 2005; Vanegas-Angaritas et al., 2007; Derera et al., 2008). However, such studies have not been conducted for popcorn germplasm in Brazil and worldwide.

Since the beginning of popcorn breeding in Brazil, which dates back to 1932 (Rangel et al., 2008), many breeding efforts have been made to develop superior genotypes. For this purpose, there are several areas of focus nowadays, namely cytogenetic (Ricci et al., 2007a,b; Silva et al., 2007), genetic diversity (Dandolini et al., 2008; Vilela et al., 2008), quality of seeds (Moterle et al., 2008), plant pathology (Vieira et al., 2009a), agronomic performance (Vendruscolo et al., 2001; Vieira et al., 2009b), and breeding methods (Simon et al., 2004; Daros et al., 2004a,b; Scapim et al., 2006; Rangel et al., 2008; Rodovalho et al., 2008; Santos et al., 2008; Arnhold et al., 2009; Freitas Júnior et al., 2006, 2009).

Diallel analysis has been applied to genetic studies of popcorn related to yield and popping expansion (Andrade et al., 2002; Scapim et al., 2002; Pinto et al., 2007; Vieira et al., 2009c). Griffing's (1956) diallel analysis provides information about the combining ability of genotypes and regarding the effect of genes on inheritance of traits. This methodology measures general combining ability (GCA), which provides information on the average behavior of parents as well as about the expression of additive gene effects. In addition, the effects of nonadditive genes are indicated by specific combining ability (SCA). Based on this approach, high positive or negative $\hat{\mathrm{g}}_{\mathrm{i}}$ values indicate that GCA of the parent has greater influence on increasing or decreasing traits in their descendent hybrids. Regarding SCA, the $\hat{\mathrm{s}}_{\mathrm{ij}}$ effects represent the deviations of each hybrid combination from the expected values by GCÄ. Estimated $\hat{\mathrm{s}}_{\mathrm{ij}}$ values are used to infer which genotypes have appropriate genetic complementation, expressing the best trait indexes among the hybrids. For leaf disease control, negative values of $\hat{\mathrm{g}}_{\mathrm{i}}$ and $\hat{\mathrm{s}}_{\mathrm{ij}}$ indicate genetic contribution to resistance.

Therefore, the objectives of this study were to estimate GCA and SCA as well as to 
examine gene effects on resistance to northern leaf blight (E. turcicum) and to gray leaf spot (C. zeae-maydis) in a set of nine popcorn inbred lines. This study aimed to provide information for the development of genotypes with appropriate genetic resistance levels.

\section{MATERIAL AND METHODS}

Nine popcorn (Zea mays L.) inbred lines in the 7th endogamic stage (Table 1) were crossed in a complete diallel scheme without reciprocals, which provided $36 \mathrm{~F}_{1}$ hybrid combinations. These inbreds were extensively tested for grain yield and popping expansion, but they were not previously selected or specifically tested for leaf disease resistance. For obtaining the hybrids, the inbreds were planted at $0.90 \mathrm{~m}$ between rows and $0.40 \mathrm{~m}$ between plants, in February 2008. Kraft paper bags were used to collect the pollen grains at flowering. Manual pollinations were then carried out for each pair of inbreds.

\begin{tabular}{|c|c|c|c|c|}
\hline \multirow[t]{2}{*}{ Inbred line } & \multicolumn{2}{|c|}{ Genetic base } & \multicolumn{2}{|c|}{ Reaction $^{1}$} \\
\hline & Genotype & Genealogy & Northern leaf blight & Gray leaf spot \\
\hline$P_{1}$ & Three-way hybrid Zélia/Pioneer & Temperate and tropical inbreds & $\mathrm{S}^{2}$ & $\mathrm{~S}^{2}$ \\
\hline $\mathrm{P}_{3}$ & Open pollinated variety CMS-42/Embrapa & Tropical inbreds & $\mathrm{IR}^{3}$ & $\mathrm{nk}$ \\
\hline $\mathrm{P}_{4}$ & Open pollinated variety CMS-43/Embrapa & Tropical inbreds & $\mathrm{IR}^{3}$ & $\mathrm{nk}$ \\
\hline $\mathrm{P}_{4.3}^{4}$ & Open pollinated variety CMS-43/Embrapa & Tropical inbreds & $\mathrm{IR}^{3}$ & $\mathrm{nk}$ \\
\hline $\mathrm{P}_{5}^{4.3}$ & Open pollinated variety UEM-J1/UEM & South American races of tropics & $\mathrm{IR}^{3}$ & $\mathrm{nk}$ \\
\hline $\mathrm{P}_{7}^{3}$ & Open pollinated variety UEM-M2/UEM & Tropical inbreds & $\mathrm{IR}^{3}$ & $\mathrm{nk}$ \\
\hline $\mathrm{P}_{7.4}$ & Open pollinated variety UEM-M2/UEM & Tropical inbreds & $\mathrm{IR}^{3}$ & nk \\
\hline $\mathrm{P}_{8}$ & Three-way hybrid 'Zaeli' & Temperate inbreds & $\mathrm{nk}$ & $\mathrm{nk}$ \\
\hline $\mathrm{P}_{0}^{8}$ & Modified one-way hybrid IAC112/IAC & Temperate and tropical inbreds & $\mathrm{R}^{2}$ & $\mathrm{nk}$ \\
\hline
\end{tabular}

${ }^{1} \mathrm{R}=$ resistant; $\mathrm{IR}=$ intermediate resistant; $\mathrm{S}=$ susceptible; $\mathrm{nk}=$ not known. ${ }^{2}$ According to Cruz and Pereira Filho (2008). ${ }^{3}$ Expected considering successive selection cycles for other traits, reported by Scapim et al. (2002).

Experimental trials were carried out over two cropping seasons in an experimental area of the State University of Maringá, in Maringá County, Northwest Paraná State, Brazil. Both trials had a $6 \times 6$-square lattice design, with three replications. In the first trial, the 36 $\mathrm{F}_{1}$ hybrids were sowed in September 2008, and in the second one the hybrids were sowed in February 2009. The commercial hybrid IAC112 was included as check treatment by additional side plots. The plot was a row $5 \mathrm{~m}$ long with 25 plants. Plots were fertilized at sowing with $50 \mathrm{~kg} / \mathrm{ha} \mathrm{K} \mathrm{O}_{2}, 20 \mathrm{~kg} / \mathrm{ha} \mathrm{N}$, and $50 \mathrm{~kg} / \mathrm{ha} \mathrm{P}_{2} \mathrm{O}_{5}$, and at the $\mathrm{V}_{4}$ growth stage with $100 \mathrm{~kg} / \mathrm{ha} \mathrm{N}$. Crop management in the experimental area followed the corn cropping recommendations for Southern Brazil. Foliar applications of fungicides were not used.

Severities of NLB and GLS were evaluated under natural infestation conditions at the $\mathrm{R}_{4}$ corn growth stage. Three leaves (1st leaf below the ear-leaf, ear-leaf, and 1st leaf above the ear-leaf) were assessed in four plants per plot. Diagrammatic scales were used for aiding the estimates of severity (Smith, 1989; Pataky, 1992).

Brown and Forsythe's variation of the Levene test and the Kolmogorov-Smirnov method were implemented for examining traits about the homogeneity of variances and normal distribution of errors. Data transformation was not necessary. After these procedures, the data set from each cropping season was examined by analysis of variance (ANOVA). ANOVA was performed considering a statistical model of lattice intrablock analysis with adjusted treatments 
and blocks within unadjusted replications, as follows: $Y_{i l(j)}=\mu+t_{i}+r_{j}+(b / r)_{l(j)}+\varepsilon_{i l(j)}$, in which $Y_{i l(j)}$ : observed values of $i^{\text {th }} \mathrm{F}_{1}$ hybrid $(i=1$ to 36$)$ into block $l^{\text {th }}(l=1$ to 6$)$ and replication $j^{\text {th }}(j=$ 1 to 3$) ; \mu$ : overall mean of the trait; $t_{i}$ : effect of the $i^{\text {th }} \mathrm{F}_{1}$ hybrid; $r_{j}$ : effect of the $j^{\text {th }}$ replication; $(b / r)_{l(j)}$ : effect of $l^{\text {th }}$ block into the $j^{\text {th }}$ replication; $\varepsilon_{i l(j)}$ : random error for each $i l(j)$ observation.

The homogeneity of the residual variances among cropping seasons was examined by the F-maximum test at $5 \%$ probability. Joint analysis of variance was carried out considering a statistical model of lattice intrablock analysis with adjusted treatments and blocks within unadjusted replications over the two cropping seasons. This statistical model is as follows: $Y_{i l(j) m}=\mu+t_{i}+r_{j}+(b / r)$ lij) $+c s_{m}+\left(t_{i} / c s_{m}\right)_{i m}+\varepsilon_{i l(j)}$, in which $Y_{i(j) m}$ : observed values of $i^{\text {th }} \mathrm{F}_{1}$ hybrid $(i=1$ to 36$)$ into block $l^{\text {th }}$ ( $l=1$ to 6$)$ and replication $j^{\text {th }}(j=1$ to 3$)$ at the $m^{\text {th }}$ cropping season $(m=1$ or 2$) ; \mu$ : overall mean of the trait; $t_{i}$ : effect of the $i^{\text {th }} \mathrm{F}_{1}$ hybrid; $r_{j}$ : effect of the $j^{\text {th }}$ replication; $(b / r)_{l(j)}$ : effect of $l^{\text {th }}$ block into the $j^{\text {th }}$ replication; $c s_{m}$ : effect of $m^{\text {th }}$ cropping season; $\left(t_{i} / c s_{m}\right)_{i m}$ : effect of interaction between the $i^{\text {th }} \mathrm{F}_{1}$ hybrid and the $m^{\text {th }}$ cropping season; $\varepsilon_{i(j)}$ : random error for each $i l(j) m$ observation. For joint analysis, entries, blocks and cropping seasons were considered to be as random model effects. Pooled error mean square was used to examine the significance of the sources of variation.

Mean adjustments of NLB and GLS severity values were obtained for each cropping season as well as for the combined seasons. It followed individual and joint statistical models for ANOVA. Adjusted means were used for individual and joint diallel analyses, following method IV, model I, proposed by Griffing (1956). Based on this procedure, the sum of squares from entries was partitioned into GCA and SCA, and their interactions with cropping season were estimated.

In the joint diallel analysis, the variance components for GCA and SCA were estimated considering a random effect model. These components were used to decide whether GCA or SCA would be the most important for NLB and GLS resistance, helping to indicate the appropriate breeding techniques.

Tests of presuppositions and ANOVA procedures were performed by SAS 9.1, Windows version (SAS Institute, Cary, NC). Individual and joint diallel analyses were carried out using the Genes program.

\section{RESULTS}

The F-maximum test did not disclose heterogeneity $(\mathrm{P}<0.05)$ for mean square errors of individual analyses for NLB and GLS severities. Thus, it was possible to perform joint analysis considering the two cropping seasons. For both diseases, joint analysis indicated significant differences $(\mathrm{P}<0.01)$ for mean squares from entries, cropping season and interaction between entries and cropping seasons (Table 2).

$\begin{aligned} & \text { Table 2. Analysis of variance for severities of northern leaf blight (Exserohilum turcicum) and of gray leaf spot } \\
& \text { (Cercospora zeae-maydis) in popcorn hybrids from complete diallel crosses over two cropping seasons. }\end{aligned}$
\begin{tabular}{lccc}
\hline Sources of variation & d.f. & \multicolumn{2}{c}{ Mean square for severity of } \\
\cline { 2 - 4 } & & Northern leaf blight & Gray leaf spot \\
\hline Entries (E) & 35 & $205.23^{*}$ & $11.19^{*}$ \\
Replication & 2 & $27.05^{\text {ns }}$ & $5.64^{\text {ns }}$ \\
Blocks within replication & 15 & $23.42^{\text {ns }}$ & $2.61^{\text {ns }}$ \\
Cropping season (CS) & 1 & $156.06^{*}$ & $25.48^{*}$ \\
E vs CS & 35 & $41.75^{*}$ & $4.67^{*}$ \\
Pooled error & 127 & 22.48 & 2.07 \\
\hline
\end{tabular}

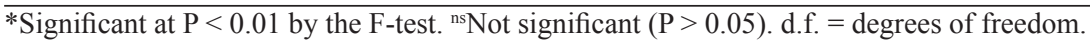


In the first trial, the adjusted means for NLB severity ranged from $2.40\left(\mathrm{P}_{4.3} \times \mathrm{P}_{8}\right)$ to $38.80 \%\left(\mathrm{P}_{1} \times \mathrm{P}_{7.4}\right)$ among the hybrid combinations (Table 3$)$. For the second trial, the NLB adjusted severity means were from $0.00\left(\mathrm{P}_{3} \times \mathrm{P}_{8}\right)$ to $24.90 \%\left(\mathrm{P}_{1} \times \mathrm{P}_{7.4}\right)$ (Table 3). Considering the joint analysis, the adjusted means for NLB ranged from $3.00\left(\mathrm{P}_{8} \times \mathrm{P}_{9}\right)$ to $31.80 \%\left(\mathrm{P}_{1} \times \mathrm{P}_{7.4}\right)$. This denoted variability among the parental inbreds and among the hybrids, which allows breeding for this trait. Regarding the adjusted means of NLB severity in the joint analysis, the hybrid combinations $\mathrm{P}_{8} \times \mathrm{P}_{9}(3.0 \%), \mathrm{P}_{3} \times \mathrm{P}_{8}(3.4 \%), \mathrm{P}_{4.3} \times \mathrm{P}_{8}(3.6 \%), \mathrm{P}_{4} \times \mathrm{P}_{9}(5.1 \%), \mathrm{P}_{7} \times \mathrm{P}_{8}(5.6 \%), \mathrm{P}_{5} \times \mathrm{P}_{9}(5.4 \%)$, $\mathrm{P}_{7.4} \times \mathrm{P}_{8}(5.8 \%), \mathrm{P}_{7} \times \mathrm{P}_{9}(6.0 \%), \mathrm{P}_{4} \times \mathrm{P}_{8}(6.1 \%), \mathrm{P}_{3} \times \mathrm{P}_{9}(6.2 \%), \mathrm{P}_{4.3} \times \mathrm{P}_{9}(7.2 \%), \mathrm{P}_{5} \times \mathrm{P}_{8}(7.4 \%)$, $\mathrm{P}_{7.4} \times \mathrm{P}_{8}(8.0 \%), \mathrm{P}_{1} \times \mathrm{P}_{8}(8.3 \%)$ were the most outstanding when compared to the check treatment IAC112 (7.1\%), which is a resistant standard according to Cruz and Pereira Filho (2008).

\begin{tabular}{|c|c|c|c|c|c|c|}
\hline \multirow[t]{3}{*}{ Hybrid } & \multicolumn{6}{|c|}{ Severity (\%) } \\
\hline & \multicolumn{3}{|c|}{ Northern leaf blight } & \multicolumn{3}{|c|}{ Gray leaf spot } \\
\hline & $1 \mathrm{st}$ & 2nd & Both & $1 \mathrm{st}$ & 2 nd & Both \\
\hline $\mathrm{P}_{1} \times \mathrm{P}_{3}$ & 23.3 & 24.8 & 24.1 & 0.3 & 3.1 & 1.7 \\
\hline $\mathrm{P}_{1}^{1} \times \mathrm{P}_{4}^{3}$ & 27.8 & 19.1 & 23.4 & 1.6 & 2.0 & 1.8 \\
\hline $\mathrm{P}_{1}^{1} \times \mathrm{P}_{4}^{4}$ & 17.3 & 15.2 & 16.3 & 0.3 & 2.2 & 1.3 \\
\hline $\mathrm{P}_{1}^{1} \times \mathrm{P}_{5}^{4.3}$ & 15.6 & 11.3 & 13.4 & 4.6 & 2.9 & 3.8 \\
\hline $\mathrm{P}_{1}^{1} \times \mathrm{P}_{7}^{5}$ & 21.4 & 9.6 & 15.5 & 2.8 & 3.1 & 2.9 \\
\hline $\mathrm{P}_{1}^{1} \times \mathrm{P}_{74}^{7}$ & 38.8 & 24.9 & 31.8 & 1.5 & 1.9 & 1.7 \\
\hline $\mathrm{P}_{1}^{1} \times \mathrm{P}^{7.4}$ & 10.8 & 5.9 & $\begin{array}{r}8.0 \\
8.3\end{array}$ & 1.5 & 4.6 & 3.0 \\
\hline $\mathrm{P}_{1}^{1} \times \mathrm{P}_{0}^{8}$ & 11.3 & 8.3 & 9.8 & 2.5 & 4.5 & 3.5 \\
\hline $\mathrm{P}_{3}^{1} \times \mathrm{P}_{4}^{9}$ & 6.7 & 10.5 & 8.6 & 1.7 & 2.0 & 1.8 \\
\hline $\mathrm{P}_{3} \times \mathrm{P}^{4}$ & 11.3 & 10.0 & $\begin{array}{r}10.6 \\
0.6\end{array}$ & 1.0 & 1.4 & $\begin{array}{l}1.0 \\
1.2\end{array}$ \\
\hline $\mathrm{P}_{3}^{3} \times \mathrm{P}_{5}^{4.3}$ & 10.8 & 9.9 & 10.3 & 4.3 & 1.9 & 3.1 \\
\hline $\mathrm{P}_{3}^{3} \times \mathrm{P}_{7}^{5}$ & 11.1 & 11.5 & 11.3 & 4.4 & 2.0 & 3.2 \\
\hline $\mathrm{P}_{3} \times \mathrm{P}_{7}^{7}$ & 20.6 & 21.3 & 21.0 & 2.3 & 2.6 & 2.4 \\
\hline $\mathrm{P}_{3} \times \mathrm{P}_{8}^{7.4}$ & 7.4 & 0.0 & 3.4 & 1.0 & 1.1 & 1.1 \\
\hline $\mathrm{P}_{3}^{3} \times \mathrm{P}_{0}^{8}$ & 6.7 & 5.7 & 6.2 & 2.0 & 3.8 & 2.9 \\
\hline $\mathrm{P}_{4}^{3} \times \mathrm{P}_{4}^{9}$ & 8.1 & 11.6 & 9.9 & 3.3 & 1.6 & 2.4 \\
\hline $\mathrm{P}^{4} \times \mathrm{P}_{5}^{4.3}$ & 11.7 & 13.9 & 12.8 & 5.1 & 3.6 & 4.3 \\
\hline $\mathrm{P}_{4}^{4} \times \mathrm{P}_{7}^{5}$ & 11.3 & 13.0 & 12.1 & 3.8 & 2.5 & 3.1 \\
\hline $\mathrm{P}_{4}^{4} \times \mathrm{P}_{7}^{7}$ & 26.4 & 21.0 & 23.7 & 3.2 & 1.9 & 2.5 \\
\hline $\mathrm{P}_{4}^{4} \times \mathrm{P}_{8}^{7.4}$ & 6.3 & 6.0 & 6.1 & 1.6 & 2.7 & 2.2 \\
\hline $\mathrm{P}^{4} \times \mathrm{P}_{0}^{8}$ & 4.6 & 5.6 & 5.1 & $\begin{array}{l}1.0 \\
2.9\end{array}$ & 3.0 & 2.9 \\
\hline $\begin{array}{l}4 \\
P^{4} \times P_{9}\end{array}$ & 11.4 & $\begin{array}{r}3.0 \\
14.2\end{array}$ & $\begin{array}{r}.1 \\
12.8\end{array}$ & 4.4 & 3.1 & 3.7 \\
\hline $\mathrm{P}_{4,3}^{4.3} \times \mathrm{P}^{5}$ & 11.9 & 10.9 & 11.4 & $\begin{array}{l}4.4 \\
2.9\end{array}$ & $\begin{array}{l}3.1 \\
2.2\end{array}$ & 2.5 \\
\hline $\mathrm{P}^{4.3} \times \mathrm{P}_{7}^{7}$ & 11.9 & 19.0 & 15.5 & 2.3 & 2.3 & 2.3 \\
\hline $\mathrm{P}^{4.3} \times \mathrm{P}^{7.4}$ & 2.4 & 4.8 & 3.6 & 0.0 & 2.7 & 1.3 \\
\hline $\mathrm{P}_{43,3}^{4.3} \times \mathrm{P}_{0}^{8}$ & 8.7 & $\begin{array}{l}5.0 \\
5.6\end{array}$ & $\begin{array}{l}7.0 \\
7.2\end{array}$ & $\begin{array}{l}0.0 \\
1.4\end{array}$ & 2.4 & $\begin{array}{l}1.3 \\
1.9\end{array}$ \\
\hline $\mathrm{P}_{5}^{4.3} \times \mathrm{P}_{7}$ & 9.1 & 11.0 & 10.1 & 5.2 & 4.4 & 4.8 \\
\hline $\mathrm{P}^{5} \times \mathrm{P}^{7}$ & 13.3 & 9.3 & 11.3 & 3.8 & 5.3 & 4.5 \\
\hline $\mathrm{P}_{5}^{5} \times \mathrm{P}_{8}^{7.4}$ & 6.6 & 8.2 & 7.4 & 2.0 & 1.6 & 1.8 \\
\hline $\mathrm{P}_{5}^{5} \times \mathrm{P}_{9}^{8}$ & 3.1 & 7.7 & 5.4 & 5.9 & 4.8 & 5.4 \\
\hline $\mathrm{P}_{7}^{5} \times \mathrm{P}_{7}^{9}$ & $\begin{array}{r}3.1 \\
17.7\end{array}$ & 8.1 & $\begin{array}{r}12.9 \\
\end{array}$ & 3.6 & $\begin{array}{l}.0 .0 \\
6.8\end{array}$ & 5.2 \\
\hline $\mathrm{P}^{7} \times \mathrm{P}^{7.4}$ & 6.1 & 5.0 & 5.6 & 1.9 & 4.3 & 3.1 \\
\hline $\mathrm{P}_{7}^{7} \times \mathrm{P}_{9}^{8}$ & 7.8 & 4.2 & 6.0 & 6.1 & 10.0 & 8.1 \\
\hline $\mathrm{P}^{7} \times \mathrm{P}^{9}$ & 8.6 & 7.4 & 8.0 & 2.1 & 5.2 & $\begin{array}{l}3.1 \\
3.6\end{array}$ \\
\hline $\mathrm{P}_{74,4}^{7.4} \mathrm{P}_{8}^{8}$ & 8.9 & 2.6 & 5.8 & 4.6 & 7.9 & 6.2 \\
\hline $\mathrm{P}_{8}^{7.4} \times \mathrm{P}_{9}^{8}$ & 3.4 & 2.6 & 3.0 & 0.5 & 5.8 & 3.1 \\
\hline IẢC112 & 5.9 & 8.3 & 7.1 & 1.3 & 3.6 & 2.5 \\
\hline
\end{tabular}

For GLS severity, the adjusted means were from $6.1\left(\mathrm{P}_{7} \times \mathrm{P}_{9}\right)$ to $0.0 \%\left(\mathrm{P}_{4.3} \times \mathrm{P}_{8}\right)$ in the first trial, and from $10.0\left(\mathrm{P}_{7} \times \mathrm{P}_{9}\right)$ to $1.1 \%\left(\mathrm{P}_{3} \times \mathrm{P}_{8}\right)$ in the second trial. Considering the joint analysis, the adjusted means ranged from $8.1\left(\mathrm{P}_{7} \times \mathrm{P}_{9}\right)$ to $1.1\left(\mathrm{P}_{3} \times \mathrm{P}_{8}\right)$. As the resistance reaction of the check treatment, IAC112, to GLS is unknown, the most outstanding hybrids from this 
study were those that showed the lower GLS severity levels in the individual and joint analyses. These hybrids and their GLS severity means in the joint analysis were: $\mathrm{P}_{3} \mathrm{xP}_{8}(1.1 \%), \mathrm{P}_{3} \times \mathrm{P}_{4.3}$ (1.2\%), $\mathrm{P}_{4.3} \times \mathrm{P}_{8}(1.3 \%), \mathrm{P}_{1} \times \mathrm{P}_{7.4}(1.7 \%), \mathrm{P}_{3} \times \mathrm{P}_{4}(1.8 \%), \mathrm{P}_{5} \times \mathrm{P}_{8}(1.8 \%)$, and $\mathrm{P}_{4.3} \times \mathrm{P}_{9}(1.9 \%)$.

Mean squares for GCA and SCA were significant by the F-test $(\mathrm{P}<0.10)$ for both NLB and GLS (Table 4). This indicated that both additive and nonadditive gene effects contributed to genetic resistance to NLB and GLS in the set of inbred lines. The relative magnitude of GCA and SCA by the variance components for random effects model indicated that additive gene effects accounted for major partitioning of variation among crosses for both diseases (Table 4). Significant mean squares were verified for the interaction between entries and cropping seasons. By partitioning this interaction value into GCA and SCA versus cropping seasons, only the GCA versus cropping season interaction was detected (Table 4).

\begin{tabular}{|c|c|c|c|}
\hline \multirow[t]{2}{*}{ Source of variation } & \multirow[t]{2}{*}{ d.f. } & \multicolumn{2}{|c|}{ Mean square (MS) for severity of } \\
\hline & & Northern leaf blight & Gray leaf spo \\
\hline Entries (E) & 35 & $260.76^{*}$ & $13.61^{*}$ \\
\hline General combining ability (GCA) & 8 & $888.87^{*}$ & $42.78^{*}$ \\
\hline Specific combining ability (SCA) & 27 & $74.65^{*}$ & $4.98^{*}$ \\
\hline Cropping season (CS) & 1 & 152.51 & 25.63 \\
\hline $\mathrm{E} v s \mathrm{CS}$ & 35 & $32.33^{*}$ & $5.59^{*}$ \\
\hline $\mathrm{GCA} v s \mathrm{CS}$ & 8 & $69.37^{*}$ & $15.85^{*}$ \\
\hline $\mathrm{SCA} v s \mathrm{CS}$ & 27 & $21.35^{\text {ns }}$ & $2.56^{\mathrm{ns}}$ \\
\hline Pooled error & 110 & 19.84 & 1.82 \\
\hline$\hat{\sigma}^{2} \mathrm{GCA}^{1}$ & & 116.32 & 5.40 \\
\hline$\hat{\sigma}^{2} \mathrm{SCA}^{2}$ & & 54.81 & 3.16 \\
\hline
\end{tabular}

${ }^{*}$ Significant at $\mathrm{P}<0.10$ by the F-test. ${ }^{\text {ns }}$ Not significant $(\mathrm{P}>0.10) .{ }^{1}$ Variance component for GCA considering random effect model $\left(\mathrm{MS}_{\mathrm{GCA}}-\mathrm{MS}_{\mathrm{SCA}} / \mathrm{p}-2\right) .{ }^{2}$ Variance component for SCA considering random effect model $\left(\mathrm{MS}_{\mathrm{SCA}}\right.$ $\left.\mathrm{MS}_{\text {pooled error }}\right)$. d.f. $=$ degrees of freedom.

Considering the individual diallel analyses, the highest negative $\hat{\mathrm{g}}_{\mathrm{i}}$ values for NLB were found with the inbred lines $\mathrm{P}_{8}(-6.60), \mathrm{P}_{9}(-6.19), \mathrm{P}_{5}(-2.32)$, and $\mathrm{P}_{4.3}(-2.12)$ in the first trial, and only with the inbred lines $\mathrm{P}_{8}(-6.35), \mathrm{P}_{9}(-6.01)$ in the second trial (Table 5). It means that these inbred lines could contribute to greater NLB resistance levels, espe-

Table 5. Estimated values (in the 1st, 2 nd or both trials) of general combining ability (GCA) effects $\left(\hat{\mathrm{g}}_{\mathrm{j}}\right)$ for northern leaf blight (Exserohilum turcicum) and gray leaf spot (Cercospora zeae-maydis) resistance in 9 popcorn inbred lines (Maringá, Brazil, 2008/2009).

\begin{tabular}{|c|c|c|c|c|c|c|}
\hline \multirow[t]{3}{*}{ Inbred line } & \multicolumn{6}{|c|}{$\hat{\mathrm{g}}_{\mathrm{i}}$} \\
\hline & \multicolumn{3}{|c|}{ Northern leaf blight } & \multicolumn{3}{|c|}{ Gray leaf spot } \\
\hline & $1 \mathrm{st}$ & 2 nd & Both & $1 \mathrm{st}$ & 2nd & Both \\
\hline$P_{1}$ & 9.78 & 4.96 & 7.37 & -0.97 & -0.44 & -0.70 \\
\hline $\mathrm{P}_{3}$ & 0.01 & 1.33 & 0.67 & -0.70 & -1.35 & -1.03 \\
\hline $\mathrm{P}^{3}$ & 0.73 & 2.33 & 1.53 & 0.19 & -1.15 & -0.48 \\
\hline $\mathrm{P}_{43}^{4}$ & -2.12 & 0.99 & -0.56 & -0.90 & -1.35 & -1.13 \\
\hline$P_{5}$ & -2.32 & 0.16 & -1.08 & 1.92 & 0.03 & 0.98 \\
\hline $\mathrm{P}_{7}$ & -0.20 & -1.58 & -0.89 & 1.26 & 1.13 & 1.20 \\
\hline $\mathrm{P}_{7.4}^{\prime}$ & 6.91 & 4.18 & 5.54 & 0.22 & 0.93 & 0.58 \\
\hline $\mathrm{P}_{8}$ & -6.60 & -6.35 & -6.50 & -1.61 & 0.09 & -0.76 \\
\hline $\mathrm{P}_{9}^{8}$ & -6.19 & -6.01 & -6.10 & 0.58 & 2.12 & 1.35 \\
\hline SD $\hat{g}_{i}$ & 0.75 & 1.06 & 0.91 & 0.26 & 0.29 & 0.28 \\
\hline $\mathrm{SD} \hat{\mathrm{g}}_{\mathrm{i}}-\hat{\mathrm{g}}_{\mathrm{j}}$ & 1.13 & 1.59 & 1.36 & 0.40 & 0.44 & 0.42 \\
\hline
\end{tabular}


cially $\mathrm{P}_{8}$ and $\mathrm{P}_{9}$, unlike lines $\mathrm{P}_{1}, \mathrm{P}_{4}$ and $\mathrm{P}_{7.4}$, which showed high positive $\hat{\mathrm{g}}_{\mathrm{i}}$ values and then tended to produce susceptible hybrids. For GLS, important negative $\hat{\mathrm{g}}_{\mathrm{i}}$ values were found for $\mathrm{P}_{8}(-1.61), \mathrm{P}_{1}(-0.97), \mathrm{P}_{4.3}(-0.90)$, and $\mathrm{P}_{3}(-0.70)$ in the first trial, and with the inbred lines $\mathrm{P}_{3}(-1.35), \mathrm{P}_{4.3}(-1.35)$ and $\mathrm{P}_{4}(-1.15)$ in the second trial (Table 5). This indicated that these inbred lines, especially $\mathrm{P}_{3}$ and $\mathrm{P}_{4.3}$, can lead to reduction in GLS severity. On the contrary, $\mathrm{P}_{5}, \mathrm{P}_{7}$ and $\mathrm{P}_{9}$ contributed to GLS susceptibility in their hybrid combinations.

Examining the estimated $\hat{\mathrm{s}}_{\mathrm{ij}}$ values from joint analysis, the hybrid combinations $\mathrm{P}_{7.4}$ x $\mathrm{P}_{8}$ and $\mathrm{P}_{3} \times \mathrm{P}_{4}$ were promising genotypes for controlling NLB by genetic resistance (Table 6). Even though $\mathrm{P}_{74} \times \mathrm{P}_{8}$ was considered to be the most outstanding due to having a parental inbred with high negative $\hat{g}_{i}$. On the contrary, hybrids $\mathrm{P}_{1} \times \mathrm{P}_{74}$ and $\mathrm{P}_{4} \times \mathrm{P}_{7}$ showed high positive $\hat{\mathrm{s}}_{\mathrm{i}}$, performing worse than the expected based on GCA of its parental inbred lines. In short, it means that the NLB severity levels shown by these hybrids were higher than expected levels, in accordance with GCA of their parental inbred lines.

\begin{tabular}{|c|c|c|c|c|c|c|}
\hline \multirow[t]{3}{*}{ Hybrid } & \multicolumn{6}{|c|}{$\hat{\mathrm{s}}_{\mathrm{ij}}$} \\
\hline & \multicolumn{3}{|c|}{ Northern leaf blight } & \multicolumn{3}{|c|}{ Gray leaf spot } \\
\hline & $1 \mathrm{st}$ & 2nd & Both & $1 \mathrm{st}$ & 2nd & Both \\
\hline $\mathrm{P}_{1} \times \mathrm{P}_{3}$ & 1.23 & 7.96 & 4.62 & -0.77 & 1.47 & 0.35 \\
\hline $\mathrm{P}_{1}^{1} \times \mathrm{P}^{3}$ & 5.06 & 1.26 & 3.16 & -0.36 & 0.17 & -0.09 \\
\hline $\mathrm{P}_{1}^{1} \times \mathrm{P}_{43}^{4}$ & -2.59 & -1.30 & -1.95 & -0.57 & 0.57 & 0.00 \\
\hline $\mathrm{P}_{1}^{1} \times \mathrm{P}_{5}^{4.3}$ & -4.09 & -4.37 & -4.23 & 0.91 & -0.11 & 0.40 \\
\hline $\mathrm{P}_{1} \times \mathrm{P}_{7}^{5}$ & -0.41 & -4.33 & -2.37 & -0.23 & -1.01 & -0.62 \\
\hline $\mathrm{P}_{1}^{1} \times \mathrm{P}_{74}^{7}$ & 9.88 & 5.22 & 7.55 & -0.49 & -2.01 & -1.25 \\
\hline $\mathrm{P}_{1} \times \mathrm{P}_{8}^{7.4}$ & -4.61 & -3.25 & -3.93 & 1.35 & 1.53 & 1.44 \\
\hline $\mathrm{P}_{1} \times \mathrm{P}_{9}^{8}$ & -4.52 & -1.20 & -2.86 & 0.16 & -0.60 & -0.22 \\
\hline $\mathrm{P}_{3} \times \mathrm{P}_{4}^{9}$ & -6.26 & -3.71 & -4.99 & -0.53 & 1.09 & 0.28 \\
\hline $\mathrm{P}_{3}^{3} \times \mathrm{P}_{43}^{4}$ & 1.18 & -2.87 & -0.85 & -0.14 & 0.69 & 0.27 \\
\hline $\mathrm{P}_{3}^{3} \times \mathrm{P}_{5}^{4.3}$ & 0.88 & -2.14 & -0.63 & 0.34 & -0.20 & 0.07 \\
\hline $\mathrm{P}_{3}^{3} \times \mathrm{P}_{7}^{5}$ & -0.94 & 1.20 & 0.13 & 1.10 & -1.20 & -0.05 \\
\hline $\mathrm{P}_{3}^{3} \times \mathrm{P}_{74}^{7}$ & 1.45 & 5.25 & 3.35 & 0.04 & -0.40 & -0.18 \\
\hline $\mathrm{P}_{3}^{3} \times \mathrm{P}_{8}^{7.4}$ & 1.76 & -5.53 & -1.88 & 0.57 & -1.06 & -0.24 \\
\hline $\mathrm{P}_{3}^{3} \times \mathrm{P}_{0}^{8}$ & 0.65 & -0.17 & 0.24 & -0.61 & -0.39 & -0.50 \\
\hline $\mathrm{P}_{4}^{3} \times \mathrm{P}_{43}^{9}$ & -2.74 & -2.27 & -2.50 & 1.27 & 0.69 & 0.98 \\
\hline $\mathrm{P}_{4}^{4} \times \mathrm{P}_{5}^{4.3}$ & 1.06 & 0.86 & 0.97 & 0.26 & 1.30 & 0.78 \\
\hline $\mathrm{P}_{4}^{4} \times \mathrm{P}_{7}^{3}$ & -1.45 & 1.70 & 0.13 & -0.39 & -0.90 & -0.64 \\
\hline $\mathrm{P}_{4}^{4} \times \mathrm{P}_{74}^{7}$ & 6.54 & 3.95 & 5.24 & 0.06 & -1.30 & -0.62 \\
\hline $\mathrm{P}_{4}^{4} \times \mathrm{P}_{8}$ & -0.05 & -0.53 & -0.29 & 0.29 & 0.34 & 0.31 \\
\hline $\mathrm{P}_{4}^{4} \times \mathrm{P}_{9}^{8}$ & -2.16 & -1.27 & -1.72 & -0.60 & -1.39 & -0.99 \\
\hline $\mathrm{P}_{4,3}^{4} \times \mathrm{P}_{5}^{9}$ & 3.61 & 2.50 & 3.06 & 0.64 & 1.00 & 0.82 \\
\hline $\mathrm{P}_{43}^{4.3} \times \mathrm{P}_{7}^{3}$ & 1.99 & 0.95 & 1.47 & -0.20 & -1.00 & -0.60 \\
\hline $\mathrm{P}_{43}^{4.3} \times \mathrm{P}_{74}^{7}$ & -5.12 & 3.29 & -0.92 & 0.24 & -0.70 & -0.23 \\
\hline $\mathrm{P}_{43}^{4.3} \times \mathrm{P}_{8}^{7.4}$ & -1.11 & -0.38 & -0.75 & -0.23 & 0.54 & 0.16 \\
\hline $\mathrm{P}_{4.3}^{4.3} \times \mathrm{P}_{9}^{8}$ & 4.78 & 0.08 & 2.43 & -1.01 & -1.79 & -1.40 \\
\hline $\mathrm{P}_{5} \times \mathrm{P}_{7}$ & -0.61 & 1.88 & 0.63 & -0.71 & -0.19 & -0.45 \\
\hline $\mathrm{P}_{5}^{5} \times \mathrm{P}_{74}^{\prime}$ & -3.52 & -5.58 & -4.55 & -1.07 & 0.91 & -0.08 \\
\hline $\mathrm{P}_{5}^{5} \times \mathrm{P}_{8}^{7.4}$ & 3.29 & 3.85 & 3.57 & -1.04 & -1.94 & -1.49 \\
\hline $\mathrm{P}_{5}^{5} \times \mathrm{P}_{9}^{8}$ & -0.62 & 3.00 & 1.19 & 0.67 & -0.77 & -0.05 \\
\hline $\mathrm{P}_{7}^{5} \times \mathrm{P}_{74}^{9}$ & -1.24 & -5.04 & -3.14 & -0.61 & 1.31 & 0.35 \\
\hline $\mathrm{P}_{7}^{7} \times \mathrm{P}_{8}^{7.4}$ & 0.68 & 2.39 & 1.53 & -0.49 & -0.34 & -0.41 \\
\hline $\mathrm{P}_{7} \times \mathrm{P}_{9}^{8}$ & 1.96 & 1.25 & 1.60 & 1.53 & 3.33 & 2.43 \\
\hline $\mathrm{P}_{74}^{7} \times \mathrm{P}_{8}$ & -3.94 & -0.97 & -2.45 & 0.76 & 0.76 & 0.76 \\
\hline $\mathrm{P}_{7.4}^{7.4} \times \mathrm{P}_{8}^{8}$ & -4.05 & -6.11 & -5.08 & 1.07 & 1.43 & 1.25 \\
\hline $\mathrm{P}_{8} \times \mathrm{P}_{9}^{8}$ & 3.96 & 4.42 & 4.19 & -1.20 & 0.17 & -0.51 \\
\hline SD $\hat{s}_{i j}$ & 1.83 & 2.57 & 2.20 & 0.64 & 0.71 & 0.68 \\
\hline$S D \hat{s}_{i j}^{i j}-\hat{s}_{i k}$ & 2.77 & 3.88 & 3.33 & 0.97 & 1.07 & 1.02 \\
\hline$S D \hat{s}_{i j}^{1 j}-\hat{s}_{k 1}^{1 k}$ & 2.52 & 3.55 & 3.04 & 0.89 & 0.97 & 0.93 \\
\hline
\end{tabular}

$\mathrm{SD}=$ standard deviation 
For GLS, the most outstanding $\hat{\mathrm{S}}_{\mathrm{ij}}$ values from joint analysis were found for the hybrid combinations $\mathrm{P}_{5} \times \mathrm{P}_{8}(-1.49)$ and $\mathrm{P}_{4.3} \times \mathrm{P}_{9}(-1.40)$. Hence, these hybrid combinations could be promising for controlling the disease. On the other hand, the hybrids $\mathrm{P}_{7} \times \mathrm{P}_{9}\left(\hat{\mathrm{s}}_{\mathrm{ij}}\right.$ of 2.43) and $\mathrm{P}_{1} \times \mathrm{P}_{8}\left(\hat{\mathrm{s}}_{\mathrm{ij}}\right.$ of 1.44) performed worse than expected, in accordance with GCA of their parental inbred lines.

\section{DISCUSSION}

It was observed based on the variance components that additive gene effects were more prevalent than nonadditive gene effects for both NLB and GLS resistance in this set of Brazilian popcorn inbreds. In fact, heterotic effects by $\hat{s}_{\mathrm{ij}}$ values were reduced and less discrepant compared to the overall mean. Thus, the predominance of additive gene effects in the inheritance of resistance to both diseases was confirmed. Other studies also concluded that additive gene effects were greater than nonadditive ones for GLS (Thompson et al., 1987; Huff et al., 1988; Elwinger et al., 1990; Ulrich et al., 1990; Donahue et al., 1991; Gevers et al., 1994; Menkir and Ayodele, 2005; Vanegas-Angaritas et al., 2007; Derera et al., 2008) and NLB (Sigulas et al., 1988; Carson, 1995). In fact, it is believed that due to the prevalence of additive gene effects, breeding methods based on recurrent selection are more effective. In this respect, $\mathrm{P}_{8}$ and $\mathrm{P}_{9}$ were considered to be the most useful for providing NLB resistance, and $\mathrm{P}_{3}$ and $\mathrm{P}_{4.3}$ were considered to be the most useful for providing GLS resistance.

Even although additive genes were prevalent, nonadditive effects were also significant for reducing both diseases. It was demonstrated that additive and nonadditive genes act together in controlling NLB and GLS. Hence, we have to consider the average performance of an inbred in hybrid combinations and the specific hybrid combinations. Regarding GLS resistance, significant SCA effects were also reported by Huff et al. (1988), Elwinger et al. (1990), Gevers et al. (1994), and Vanegas-Angaritas et al. (2007). However, nonadditive gene effects of SCA have never been considered predominant over additive gene effects (Derera et al., 2008). In our study, some hybrid combinations were identified for successfully controlling the disease. In this respect, hybrid combinations $\mathrm{P}_{7.4} \times \mathrm{P}_{8}$ and $\mathrm{P}_{4.3} \times \mathrm{P}_{9}$ can be exploited by reciprocal recurrent selection aiming to provide populations and inbreds with resistance to both NLB and GLS.

Hallauer and Miranda Filho (1988) pointed out that external environmental factors such as weather, soil, and pests probably have a greater effect on single crosses than other types of hybrids. Single hybrids usually interact more with the environment than double-cross hybrids (Troyer, 1996). In addition, the development of diseases usually is different between environments due to the environmental conditions, which also contribute to genotype-by-environment interactions. The results for all interactions observed in the joint analysis suggest that the hybrids did not have the same relative performance across cropping seasons. In partitioning the entries versus cropping season's interaction into GCA versus cropping seasons and SCA versus cropping seasons, only the GCA versus cropping season interaction was significant $(\mathrm{P}<0.10)$. It means that SCA effects, being positive or negative, are supposed to be consistent over the two trials. This also denotes the importance of environment and genotype-environment interaction effects for these traits. In general, even though some variation in performance was observed based on the GCA versus cropping season interaction, the severity levels of NLB and GLS in the hybrids were quite consistent across the two cropping seasons. 


\title{
ACKNOWLEDGMENTS
}

\author{
Research supported by Conselho Nacional de Pesquisa (CNPq) and Fundação
} Araucária.

\section{REFERENCES}

Andrade RA, Cruz CD, Scapim CA, Silvério L, et al. (2002). Diallel analysis of the combining ability of popcorn cultivars. [Análise dialélica da capacidade combinatória de variedades de milho-pipoca]. Acta Sci. Agron. 24: 1197-1204.

Arnhold E, Viana JMS, Silva RG and Mora F (2009). Relative efficiencies of selection methods of inbred families in popcorn. [Eficiências relativas de métodos de seleção de famílias endogâmicas em milho-pipoca]. Acta Sci. Agron. 31: 203-207.

Carson ML (1995). Inheritance of latent period length in maize infected with Exserohilum turcicum. Plant Dis. 79: 581-585.

Cruz JC and Pereira Filho IA (2008). Comportamento das Cultivares de Milho Disponíveis no Mercado Brasileiro na Safra 2007/08 em Relação às Principais Doenças. In: Embrapa Milho e Sorgo, Sete Lagoas. Available at [http://www. cnpms.embrapa.br/milho/cultivares/tabela2.htm]. Accessed April 15, 2009.

Dandolini TS, Scapim CA, Amaral Júnior AT, Mangolin CA, et al. (2008). Genetic divergence in popcorn lines detected by microsatellite markers. Crop Breed. Appl. Biotechnol. 8: 313-320.

Daros M, Amaral Júnior AT, Pereira MG, Santos FS, et al. (2004a). Recurrent selection in inbred popcorn families. Sci. Agric. 61: 609-614.

Daros M, Amaral Júnior AT, Pereira MG, Santos FS, et al. (2004b). Correlations among agronomic traits in two recurrent selection cycles in popcorn. [Correlações entre caracteres agronômicos em dois ciclos de seleção recorrente em milho-pipoca]. Cienc. Rural 34: 1389-1394.

Derera J, Tongoonaa P, Pixley KV, Vivek B, et al. (2008). Gene action controlling gray leaf spot resistance in Southern African maize germplasm. Crop Sci. 48: 93-98.

Donahue PJ, Stromberg EL and Myers SL (1991). Inheritance of reaction to gray leaf spot in a diallel cross of 14 maize inbreds. Crop Sci. 31: 926-931.

Elwinger GF, Johnson MW, Hill RR Jr and Ayers JE (1990). Inheritance of resistance to gray leaf spot of corn. Crop Sci. 30: 350-358.

Freitas Júnior SP, Amaral Júnior AT, Pereira MG, Cruz CD, et al. (2006). Combining ability in popcorn by circulant diallel. [Capacidade combinatória em milho-pipoca por meio de dialelo circulante]. Pesq. Agropec. Bras. 41: 1599-1607.

Freitas Júnior SP, Amaral Júnior AT, Rangel RM and Viana AP (2009). Genetic gains in popcorn by full-sib recurrent selection. Crop Breed. Appl. Biotechnol. 9: 1-7.

Gevers HO, Lake JK and Hohls T (1994). Diallel cross analysis of resistance to gray leaf spot in maize. Plant Dis. 78: 379-383.

Griffing B (1956). Concept of general and specific combining ability in relation to diallel crossing system. Aust. J. Biol. Sci. 9: 463-493.

Hallauer AD and Miranda Filho JB (1988). Quantitative Genetics in Maize Breeding. Iowa State University Press, Ames.

Huff CA, Ayers JE and Hill RR (1988). Inheritance of resistance in corn (Zea mays) to gray leaf spot. Phytopathology 78: 790-794.

Menkir A and Ayodele M (2005). Genetic analysis of resistance to gray leaf spot of midaltitude maize inbred lines. Crop Sci. 45: 163-170.

Moterle LM, Scapim CA, Braccini AL, Rodovalho MA, et al. (2008). Influence of water stress on the physiological performance of seeds of simple hybrids of popcorn. [Influência do estresse hídrico sobre o desempenho fisiológico de sementes de híbridos simples de milho-pipoca]. Cienc. Agrotec. 32: 1810-1817.

Pataky JK (1992). Relationships between yield of sweet corn and northern leaf blight caused by Exserohilum turcicum. Phytopathology 82: 370-375.

Pinto RJB, Scapim CA, Barreto RR, Rodovalho MA, et al. (2007). Diallel analysis of popcorn imbred lines. [Análise dialélica de linhagens de milho de pipoca]. Ceres 54: 471-477.

Rangel RM, Amaral AT Jr, Scapim CA, Freitas SP Jr, et al. (2008). Genetic parameters in parents and hybrids of circulant diallel in popcorn. Genet. Mol. Res. 7: 1020-1030.

Ricci GL, Silva N, Pagliarini MS and Scapim CA (2007a). B chromosomes in popcorn (Zea mays L.). Genet. Mol. Res. 6: 137-143.

Ricci GC, Silva N, Pagliarini MS and Scapim CA (2007b). Microsporogenesis in inbred line of popcorn (Zea mays L.). 
Genet. Mol. Res. 6: 1013-1018.

Rodovalho MA, Mora F, Santos ES, Scapim CA, et al. (2008). Survival heritability in 169 families of white grain popcorn: a Bayesian approach. Cienc. Inv. Agr. 35: 303-309.

Santos FS, Amaral Júnior AT, Freitas Júnior SP, Rangel RM, et al. (2008). Genetic gain prediction of the third recurrent selection cycle in a popcorn population. Acta Sci. Agron. 30: 651-658.

Scapim CA, Pacheco CAP, Tonet A, Braccini AL, et al. (2002). Diallel analyses and heterosis in popcorn varieties. [Análise dialélica e heterose de populações de milho-pipoca]. Bragantia 61: 219-230.

Scapim CA, Braccini AL, Pinto RJB, Amaral Júnior AT, et al. (2006). Average genetic components and inbreeding depression in popcorn populations. [Componentes genéticos de médias e depressão por endogamia em populações de milho-pipoca]. Cienc. Rural 36: 36-41.

Sigulas KM, Hill RR and Ayers JE (1988). Genetic analysis of Exserohilum turcicum expansion on corn. Phytopathology 78: $149-153$.

Simon AG, Scapim CA, Pacheco CAP, Pinto RJB, et al. (2004). Inbreeding depression in popcorn populations. [Depressão por endogamia em populações de milho-pipoca]. Bragantia 63: 55-62.

Smith KL (1989). Epidemiology of Gray Leaf Spot of Field Corn (Zea mays L.) Caused by Cercospora zeae-maydis Tehon \& Daniels. Ph.D. thesis, University of Maryland, College Park.

Thompson DL, Bergquist RR, Payne GA, Bowman DT, et al. (1987). Inheritance of resistance to gray leaf spot in maize. Crop Sci. 27: 243-247.

Troyer AF (1996). Breeding widely adapted, popular maize hybrids. Euphytica 92: 163-174.

Ulrich JF, Hawk JA and Carroll RB (1990). Diallel analysis of maize inbreds for resistance to gray leaf spot. Crop Sci. 30: $1198-1200$.

Vanegas-Angaritas H, De-León C and Narro-Léon L (2007). Genetic analysis of tolerance to Cercospora ssp. in tropical maize inbred lines. [Análisis genético de la tolerancia a Cercospora spp. en líneas endogâmicas de maíz tropical]. Agrociencia 41: 35-43.

Vendruscolo ECG, Scapim CA, Pacheco CAP, Oliveira VR, et al. (2001). Adaptability and stability of popcorn cultivars in the central-south of Brazil. [Adaptabilidade e estabilidade de cultivares de milho-pipoca na região centro-sul do Brasil]. Pesq. Agropec. Bras. 36: 123-130.

Vieira RA, Tessmann DJ, Scapim CA, Hata FT, et al. (2009a). Genetic resistance of new popcorn hybrids to foliar diseases. Crop Breed. Appl. Biotechnol. 9: 140-146.

Vieira RA, Rodovalho MA, Scapim CA, Tessmann DJ, et al. (2009b). Agronomic performance of new popcorn hybrids in Northwestern Paraná State, Brazil. [Desempenho agronômico de novos híbridos de milho-pipoca no Noroeste do Estado do Paraná, Brasil]. Acta Sci. Agron. 31: 29-36.

Vieira RA, Souza Neto IL, Bignotto LS, Cruz CD, et al. (2009c). Heterotic parametrization for economically important traits in popcorn. [Parametrização heterótica para características de importância econômica em milho pipoca]. Acta Sci. Agron. 31: 411-419.

Vilela FO, Amaral Júnior AT, Pereira MG, Scapim CA, et al. (2008). Effect of recurrent selection on the genetic variability of the UNB-2U popcorn population using RAPD markers. [Efeito da seleção recorrente na população UNB-2U de milho pipoca por marcadores RAPD]. Acta Sci. Agron. 30: 25-30. 